\author{
Anna Bednarczyk \\ Uniwersytet Łódzki \\ anna.bednarczyk@uni.lodz.pl \\ ORCID: 0000-0003-2761-8647
}

\title{
GAWĘDA O BUDZIE \\ JARMARCZNEJ Z FABRYCZNYMI PRZYLEGŁOŚCIAMI W TLE
}

DOI: http://dx.doi.org/10.12775/RP.2021.001

\begin{abstract}
Zarys treści: W artykule podjęto problematykę przekładu wierszowanego felietonu, który stanowi materiał ilustracyjny do innych badań naukowych. Ten cel, podobnie jak odległość temporalna między powstaniem oryginału a powstaniem przekładu, narzuca łłumaczowi pewne wybory. Dlatego też obok prezentacji praktycznych rozwiqzań translatorskich w pracy odniesiono się do koncepcji wyboru odpowiedników spośród różnych możliwości i zaproponowano wykorzystanie teorii zbiorów rozmytych, która pozwala na nieostre określanie granic między swobodą twórczą tłumacza a koniecznością jej ograniczenia.
\end{abstract}

Słowa kluczowe: rajok, realia, ironia, potencjalność, zbiór rozmyty, cel przekładu

\author{
Niech sobie Ganges, Sorrento, Krym \\ Pod niebo inni wynosza, \\ A ja Łódź wolę! Jej brud i dym \\ Szczęściem mi są i rozkoszą! \\ $[\ldots]$ \\ I ten sterczacy głupio "Savoy", \\ I wyfioczone przekupki \\ I szyld odwieczny: „Mużskij portnoj, \\ On-że madam i pszerupki". \\ Julian Tuwim, Łódź (Tuwim: online)
}




\section{Buda jarmarczna}

Dierwsze wyjaśnienia, które zobowiązana jestem przedstawić, przystępując do niniejszych rozważań, to definicja budy jarmarcznej, a więc dawnego określenia straganu oraz budy wędrownego teatru, ale przede wszystkim wyjaśnienie, skąd wzięła się ona w tytule prezentowanych przekładoznawczych przemyśleń. Otóż Buda jarmarczna to tytuł nadany przeze mnie polskiemu przekładowi wiersza, który w oryginale nie ma wprawdzie tytułu, ale jest jednym $\mathrm{z}$ wierszowanych felietonów ukazujących się w łódzkiej rosyjskojęzycznej prasie przełomu XIX i XX wieku pod wspólną nazwą Раёшник. Autorem owego cyklu był poeta podpisujący się nazwiskiem Kuzmicz (Кузьмич). Pisząc o nim poeta, muszę jednak zaznaczyć, że wiersze tego autora trudno nazwać utworami poetyckimi. Są to teksty wierszowane przypominające to, co w Rosji nazywano раёшным стихом (wierszem rajosznym). A przecież cykl felietonów, z którego pochodzi przekładany przeze mnie tekst, nosi, jak wspomniałam, nazwę Раёшник [Rajosznik]. Czym więc są Раёшник i раёшный стих? Określenie to odnosi się do jednej z najstarszych form poezji ludowej, a zarazem do jej twórcy. Jest to, $\mathrm{z}$ jednej strony, wiersz wolny, frazowany (z uwypukloną intonacyjnie frazą), zwykle rymowany parzyście, choć nie jest to stała zasada, a jak podaje Słownik poetycki (Поэтический словарь) Aleksandra Kwiatkowskiego:

Większość ludowych sztuk teatralnych oraz teksty przedstawień ludowego teatru kukiełkowego (wertep, pietruszka, bałagan) tworzono w oparciu o formę rajka, posiadającego niezwykle dynamiczną strukturę, bardzo dogodną dla improwizowanych występów na scenie (Kviatkovskii 1966: online),

a $\mathrm{z}$ drugiej strony - autor tego rodzaju wierszowanego komentarza do prezentowanych jarmarcznej publice scen.

Jednym z rodzajów rosyjskiego teatru ludowego był „rajok” - niewielkie pudło z otworami ze szkłem powiększającym, przez które „widzowie” oglądali obrazki namalowane na pasku papieru. Jedynym aktorem owego teatru był jego właściciel - kręcący korbką „,rajosznik”. Dzięki korbce obrazki przewijały się z jednej rolki na drugą, a „rajosznik” komentował kolejne prezentacje, posługując się układanym przez siebie „rojosznym” wierszem. 


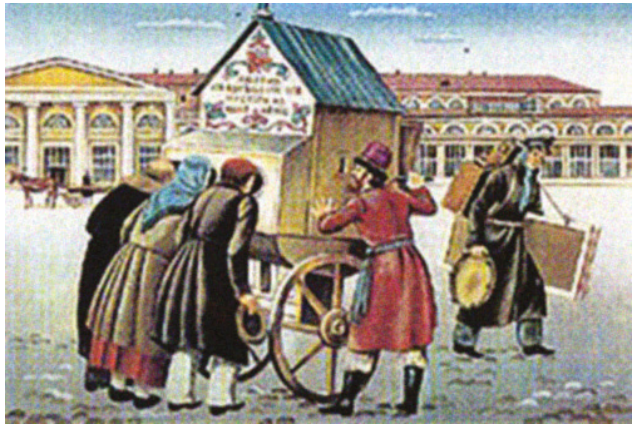

Rys. 1. Rajok,

https://pl.wikipedia.

org/wiki/Rajok

Warto przy tym wspomnieć, że tego rodzaju wierszowane teksty były również wykorzystywane przez rosyjskich poetów, np. przez Aleksandra Puszkina w bajсе Сказка о попе и о работнике его Балде (zob. Pushkin 1959-1962: 303-308) czy Demiana Biednego w rewolucyjnych wierszach propagandowych. Pobrzmiewają one także, z pewnymi kompozycyjnymi zmianami, w Dwunastu Aleksandra Błoka (zob. Błok 1918: online). Podkreślam to, aby uwypuklić nośność tej ludowej formy poetyckiej, sięganie do niej nie tylko przez twórców ludowych, ale i przez uznanych literatów, świadome wykorzystywanie jej w przypadku stylizacji na folklor i wskazywanie na pochodzenie bohatera bądź w celu odwoływania się do określonego czytelnika.

Tłumacząc tego rodzaju wiersze, nie można więc lekceważyć gatunku poetyckiego, do którego należą, a jednocześnie konieczne jest uwzględnienie odmiennych od dzisiejszych warunków ich powstawania, funkcji, jaką poezja ta pełniła w XIX wieku w Łodzi, oraz docelowej, a zatem polskiej tradycji literackiej. Ponadto trzeba wziąć pod uwagę odległość czasową między powstaniem oryginału (początek XIX stulecia) i przekładu (XXI wiek).

W tym kontekście wypada też rozpatrzyć możliwości, dane tłumaczowi dzięki pewnemu podobieństwu rosyjskich i polskich ludowych form poetyckich. Mam tu na myśli przede wszystkim pieśn dziadowską, którą $\mathrm{z}$ „rajosznym” wierszem łączy występująca w nich tematyka - obie ludowe produkcje pierwotnie prezentowały historie biblijne, a ponadto pewna sensacyjność i „nowiniarskość” prezentacji, często niespójnej, ale skomponowanej z różnych epizodów związanych wspólnym, niejednokrotnie aktualnym w momencie powstania tematem. Poza tym zwraca uwagę wyraźnie akcentowana fraza, a także częste rymy parzyste, co ważniejsze - stosunkowo 
banalne. Stąd w obu przypadkach można mówić o odczuwaniu tej „poezji” jako tandetnej. Wypada również wskazać na często satyryczny charakter zarówno „rajosznego” wiersza, jak i pieśni dziadowskiej. Ta ostatnia cecha, podobnie jak w wypadku rosyjskiego folkloru, wykorzystywana była przez polskich poetów, np. takich jak Tadeusz Boy-Żeleński czy Konstanty Ildefons Gałczyński. Co więcej, pieśń dziadowska, w tym nowiniarska, znana była w Polsce, na co w licznych artykułach i książce wskazywał Piotr Grochowski (zob. np. Grochowski 2010), dlatego jej pojawienie się w prasie łódzkiej na przełomie XIX i XX wieku nie jest zaskakujące. Moim zdaniem wszystkie te okoliczności pozwalają tłumaczowi wykorzystać podobieństwo rosyjskich oraz polskich form i funkcji w przekładzie.

Wracając natomiast do wspomnianej wcześniej różnicy funkcji pełnionych przez oryginał i przekład, wypada odnotować, że tłumaczony przeze mnie rosyjski wiersz Kuzmicza (Kuzmicz 1895) ukazał się w wydawanej w Łodzi rosyjskojęzycznej gazecie. Był on skierowany do rosyjskojęzycznego czytelnika tej prasy, ale jednocześnie do czytelnika będącego łodzianinem i doskonale orientującego się w ówczesnych problemach fabrycznego miasta. Trzeba przy tym podkreślić, że zarówno ten, jak i inne wiersze zamieszczane w łódzkiej rosyjskojęzycznej prasie traktowały o takich właśnie problemach, pełniąc funkcję szczególnego komentarza do obrazków, przesuwających się przed oczyma obywateli miasta Łodzi.

Polska „buda jarmarczna” wydała mi się najbliższym odpowiednikiem rosyjskiego tytułu cyklu, a zarazem widowiska opatrzonego satyrycznym komentarzem, o cechach niezbyt wysokich lotów rymowanki z tzw. rymami częstochowskimi. „Buda jarmarczna” stała się więc dla mnie symbolem chaotycznego ulicznego teatru rozmaitości, którego występy odbywają się na tle pejzażu fabrycznego miasta, silnie przenikającego do owych tandetnych poetycko komentarzy. Tłumaczenie powinno było ten charakter tekstu zachować i nie wzmacniać jego wartości artystycznej, tym bardziej że przekład miał służyć prezentacji łódzkiej różnorodności kulturowej sprzed II wojny światowej dzisiejszemu czytelnikowi.

W tym miejscu kilka słów należy poświęcić wspólnocie rosyjskiej, która na tle innych narodowości tworzących łódzki tygiel kulturowy była stosunkowo słaba, a przede wszystkim niezbyt liczna, co musiało rzutować także na dokonania artystyczne.

Rosjanie pojawili się w Łodzi dopiero w XIX stuleciu i pierwotnie były to tylko nieliczne rodziny. Na początku XX wieku liczba stałych mieszkańców 
narodowości rosyjskiej doszła do 900. Najliczniejsi byli w tym gronie kupcy. W następnej kolejności do Łodzi przybyło wojsko, które stacjonowało tu w liczbie około 3500 żołnierzy. Trudno więc mówić o wielkim intelektualnym potencjale gminy rosyjskiej. Nie można również zapomnieć o jej ubóstwie. Na przykład funkcję cerkwi przez wiele lat pełniło w Łodzi mieszkanie feldfebla Andriejewa, ponieważ łódzkich Rosjan nie było stać na budowę cerkwi prawosławnej z prawdziwego zdarzenia. Powstała ona dopiero w 1884 roku z datków fabrykantów łódzkich, reprezentantów wszystkich żyjących w Łodzi narodowości i wyznań. Odnotuję, że przed I wojną światową w Łodzi mieszkało na stałe 1416 Rosjan, co nie stanowiło nawet 1\% mieszkańców miasta. Niemniej w Łodzi wychodziła rosyjska prasa. Była to przede wszystkim gazeta „Лодзинский листок” [Lodzinskij listok (pol. Łódzka Kartka)], w której publikowano teksty prozatorskie i poetyckie, w tym interesujący nas cykl Раёшник, a później także „Голос Лодзи” [Golos Lodzi (pol. Głos Łodzi)]. Jak już wspomniałam, przygotowywane przeze mnie przekłady dokonane zostały w konkretnym celu, służą one prezentacji łódzkiej kulturowej różnorodności na przełomie XIX i XX wieku i wykonane zostały w ramach projektu naukowego prowadzonego na Wydziale Filologicznym UŁ. Wynika $\mathrm{z}$ tego nie tylko trudność dostosowania się do konkretnej formy przekładanych utworów, nie tylko konieczność pokonania problemów związanych $z$ tłumaczeniem $z$ jednego języka na drugi i z jednej kultury na drugą, ale także, a może nawet przede wszystkim, wymóg uwzględnienia łódzkich realiów sprzed ponad stu lat. Wszystko to dotyczy nie tylko wiersza z cyklu Раёшник, ale również innych utworów wierszowanych publikowanych w łódzkiej rosyjskojęzycznej prasie XIX i początku XX wieku.

Wracając jednak do tłumaczonego felietonu, odnotuję, że pojawiła się w nim nie tylko nazwa Łódź, ale także zjawiska związane z kryzysem oraz wskazanie na przemysłowy charakter miasta. Nie wszystkie wymienione elementy musiały znaleźć się w przekładzie, ale część niewątpliwie powinna była zostać w polskim wariancie odtworzona ze względu na potrzebę zachowania kolorytu ówczesnego miasta i cech charakterystycznych felietonu. Przy tym konieczne było zachowanie odniesień do epoki oraz satyrycznego nacechowania oryginalnego tekstu, co w oryginale przejawiało się choćby w użyciu zdrobnień i gry słów, do czego wrócę później. Stąd też w polskim wariancie znalazły się rozwiązania, które czasem odtwarzają zjawiska obserwowane w oryginale, a innym razem kompensują je, zachowując funkcjonalność tekstu. Przytoczę niektóre z nich: 


\section{Oryginał:}

В торговле застой, кризис губительный, Крахи, банкротства... Стонут решительно Фабриканты все в Лодзи; в отчаяньи $[\ldots]^{1}$ (Kuzmicz 1895)

\section{Tłumaczenie:}

W handlu trwa kryzys, zastój to straszliwy, Kupiec w boleści jęczy nieszczęśliwy, Krach i bankructwo, cała Łódź w rozpaczy Fabryki stoją, fabrykanci płaczą $[\ldots]^{2}$

\section{Tłumaczenie filologiczne:}

W handlu zastój, kryzys niszczący, Krachy, bankructwa... Jęczą zdecydowanie [straszliwie]

Fabrykanci wszyscy w Łodzi w rozpaczy [...]

W prezentowanym przekładzie zastosowano wzmocnienie emocjonalne: na miejscu rosyjskiego „niszczącego (zabójczego) kryzysu” pojawił się „zastój straszliwy", z kolei określenie ,jęczą zdecydowanie” zastąpiono kupcem, który jęczy w boleści, co dzięki zderzeniu patetycznego „w boleści” z krachem na giełdzie brzmi groteskowo.

\section{Oryginat:}

Цену собьет да еще скидочку слупит, Векселей понадаст на дальние сроки (Kuzmicz 1895)

\section{Tłumaczenie filologiczne:}

Cenę zbije i jeszcze rabacik złupi, Weksli porozdaje na długie terminy

\section{Tłumaczenie:}

Zbić cenę i jeszcze rabacikiem złupić, Weksle na termin późny z możliwością zwłoki

W tłumaczeniu udało się odtworzyć formę zdrobniałą i wywołać ten sam efekt niespójności stylistycznej, który obserwowano w rosyjskim pierwowzorze: „скидочку слупит” (rabacik złupi) - „rabacikiem złupić”.

1 Pisownia cytatów rosyjskich w całym tekście została dostosowana do współczesnych zasad, jednak formy fleksyjne pozostawiono zgodne z zapisem w oryginale. Wytłuszczenia tu i dalej w tekście - A.B.

2 Wszystkie przekłady poetyckie i filologiczne w tekście głównym - A.B. 
Oryginat:

Вопрос тот - о стачках иль о «синдикатах» (Kuzmicz 1895)

Tłumaczenie filologiczne:

Pytanie to - o rozruchach lub o „syndykatach” (związki zawodowe)

Do polskiego tekstu wprowadzony został przypis wewnętrzny: robotnicze związki - „syndykaty”, który pozwala wyjaśnić niezrozumiałe dzisiaj określenie.

Oryginał:

Известно, что из Лодзи всех изгнали Мазуриков [...]

Tłumaczenie filologiczne:

Wiadomo, że z Łodzi wygnali wszystkich Złodziei [oszustów / szalbierzy] [...]

(Kuzmicz 1895)

\section{Tłumaczenie:}

I wreszcie pytanie pojawia się znowu

$[\ldots]$

O strajki, robotnicze związki - „syndykaty”... 


\section{Oryginat:}

И вот, глядя не них и дружно, как овцы, Недавно столкнулись солеторговцы, И уж было протянули к нам свои лапки, Но, увы! Их прихлопнула пресса по шапке, Забила тревогу, заговорила

И солеторговцам так насолила,

Что те огорченные, хвостик поджавши, Ушли по домам несолоно хлебавши!

Бедные!

(Kuzmicz 1895)

\section{Tłumaczenie poetyckie:}

I już za ich przykładem, tak jak owce w stadzie

Niedawno się soli spotkali handlarze, I już wyciągnęli po nas swoje łapki, Lecz prasa im dała solidnie po czapce! $\mathrm{Na}$ alarm zabiła i tak przemówiła, Że handlarzom soli dobrze nasoliła.

Więc smutni ogonki pod siebie schowali, Biesiadując bez soli, do domów wracali! Biedacy!

\section{Tłumaczenie filologiczne:}

I oto, patrząc na nich (za ich przykładem), zgodnie, tak jak owce,

Niedawno spotkali się handlarze solą, I już wyciągali po nas swoje łapki

Lecz, cóż! Prasa dała im po czapce (nakryła ich czapką)!

Zabiła na alarm, przemówiła, I handlarzom soli tak nasoliła,

Że ci zasmuceni ogonki schowali pod siebie, Rozeszli się do domów zjadłszy bez soli (nie osiągnąwszy niczego)!

Biedacy!

Odtworzone zostało również ironiczne wykrzyknienie „Biedacy!”, zastosowane przez autora jako wyraz fałszywego współczucia. Ponadto w przekładzie odwzorowano stylistyczną niespójność między mottem a pozostałym tekstem, co również przyczynia się do jego odbioru jako wypowiedzi ironicznej w stosunku do prezentowanej rzeczywistości. Idzie tu o pierwszy wers wiersza Cтансы (pol. Stance) Wiktora Krasowa: „Я вновь пред тобою стою очарован” (pol. „Znowu stoję przed tobą oczarowany”) (Krasov przed 1841), który pojawił się w tekście Kuzmicza w charakterze motta i do którego wyraźnie odnoszą się pierwsze słowa wierszowanego felietonu:

Вновь перед тобою, дорогой читатель,

Старинный твой друг и приятель...

Здравствуй, дружочек! Дай руку,

Побеседуем, прогоним-ка скуку, 
Особливо в такое время печальное,

Как теперь - положенье скандальное:

В торговле застой $[\ldots]$.

(Kuzmicz 1895)

Tłumaczenia tekstu Krasnowa na język polski nie znalazłam, motto otrzymało więc polski odpowiednik mojego pomysłu: „Znowu przed tobą stoję w zachwyceniu", natomiast tekst Kuzmicza brzmi w wersji przekładowej:

\section{Tak, miły czytelniku, znowu jest przed tobą}

Przyjaciel twój, co wspólną dąży drogą...

Witaj mi druhu! I podaj mi rękę,

Porozmawiamy, przegnamy udrękę,

Szczególnie teraz w czasach skandalicznych,

W tych sytuacjach, realiach krytycznych:

W handlu trwa kryzys [...].

\section{Fabryczne przyległości}

Podobne problemy translatorskie pojawiają się przy każdym z rosyjskich wierszowanych komentarzy, jak również w innych wierszach traktujących o łódzkiej problematyce. Dlatego warto zwrócić uwagę właśnie na te realia, które okazały się ważne z punktu widzenia odtworzenia charakteru epoki i lokalnej specyfiki. Jak już wspomniałam, w wierszach publikowanych w rosyjskiej prasie pojawiły się wskazania na różne łódzkie toponimy. $\mathrm{Na}$ przykład w wierszu zatytułowanym Злобы дня (I.V. 1914), a po polsku Nieszczęśliwe przypadki, pojawiła się ulica Piotrkowska, w Ужель мы не идем вперед? (Kuzmicz 1896), po polsku Czyż nie jest to do przodu krok? Koluszki, w wierszu Подвиг дельного купиа (I.V. 1914) nazwanym przeze mnie Wielki wyczyn kupca-chwata, o czym będzie mowa dalej - Grand-Hotel. W dalszej części tekstu odniosę się też do zmiany, jaka nastąpiła w tytule wiersza Песня балутскаго обывателя (Dyadya Mityay 1914), który zastąpiłam Pieśnią bałuciarza, a w którym mowa jest o gminie Bałuty, obecnie jednej z dzielnic Łodzi. Ponadto w publikowanych w prasie tekstach mogą się pojawić nazwiska znanych w ówczesnych czasach łodzian, jak w wierszu 
Маленький фельетоник (Dyadya Mityay 1904)³. Znajdujemy w nim całą serię nazwisk łódzkich restauratorów przeciwstawionych fabrykantom, bankierom i kupcom, ponieważ właściciele kawiarni, cukierni oraz restauracji bogacili się niezależnie od kryzysu panującego wśród przedsiębiorców związanych z produkcją przemysłową:

\section{Вот Грицгендлер, Гуль, Яновский,} Шмагер, Ульрих и Рошковский

Не пеняют на погоду:

Им она пришла в угоду.

(Dyadya Mityay 1904)

Uznałam, że tak wyraźnie łódzką lokalizację warto w przekładzie zachować, a nawet wzmocnić ją nieco, o ile to możliwe. W wypadku ostatniego z cytowanych tekstów pewnym utrudnieniem dla translacji stały się nazwiska wspomnianych restauratorów, których zachowanie wymagało sprawdzenia polskiej pisowni, a czasem wyboru spośród różnych możliwych wariantów. Przykładem jest nazwisko właściciela kawiarni i cukierni Gricgendlera bądź Grycendlera ${ }^{4}$.W tym wypadku postanowiłam zostawić w przekładzie błędną formę nazwiska - Gricgendler, ponieważ właśnie ona (Грицгендлер) została użyta przez autora felietonu, mimo że właściciel kawiarni przy Piotrkowskiej 62 naprawdę nazywał się Fajwel Grycendler:

Lecz Gricgendler, Gul, Janowski,

Szmagier, Ulrych i Roszkowski

Nie czepiają się pogody,

Bo przyniosła im dochody.

Ponadto dla wzmocnienia efektu lokalnego nacechowania do polskiego wariantu wiersza Злобы дня (I.V. 1914) wprowadziłam Pietrynę - typowe dla łodzian zdrobnienie nazwy najsłynniejszej łódzkiej ulicy, jednocześnie podając też jej pełną nazwę, co pozwala czytelnikowi utożsamić Piotrkowską z Pietryną:

\footnotetext{
3 Pol. Maleńki felietonik.

4 Zob. „F. Grycendler. Cukiernia” oraz „Projekt przebudowy piekarni przy cukierni pana Gricgendlera...,, https://piotrkowska-nr.pl/Piotrkowska_62.
} 


\section{Pospacerować po Pietrynie}

Pójdę - tam pewnie pusto dziś,

Cicho, spokojnie życie płynie,

Cudownie tak po mieście iść.

I oto jestem na Piotrkowskiej

(Nieszczęśliwe przypadki)

Z kolei w tłumaczeniu wiersza Skaza Лодзъ (Пародия) (Skaz 1905), czyli Łódź (Parodia), znalazło się nieobecne w oryginale określenie „lodzermensz”, oznaczające bogatego, a częstokroć także chciwego obywatela Łodzi z okresu jej rozwoju jako miasta przemysłowego. Natomiast w tytule przekładu wspomnianej już Песни балутскаго обывателя ројаwiła się typowo łódzka nazwa - „bałuciarz”, czyli mieszkaniec Bałut, do 1915 roku największej polskiej wsi, ale również regionalny, łódzki synonim chuligana.

Realia to także terminy związane ze specyfiką łódzkiego przemysłu, a więc $\mathrm{z}$ włókiennictwem. Znajdujemy je też w tekstach, które teoretycznie nie powinny nawiązywać do produkcji fabrycznej. Ich „wszechobecność” świadczy moim zdaniem o pierwszoplanowym znaczeniu właśnie takiego przemysłowego charakteru rozwijającego się w XIX wieku miasta. Jako przykład posłużyć może wiersz S. Zaksa ${ }^{5}$, którego pierwsza zwrotka brzmi:

\section{Oryginal:}

Выхожу я на простор зеленый, Взор ласкающих полей и нив, Как прозрачен воздух благовонный, Как мир Божий пышен и красив! (S. Zaks 1912)

\section{Tłumaczenie filologiczne:}

Wychodzę na zieloną przestrzeń

Pieszczących wzrok pól i niw, Jak przezroczyste jest wonne powietrze, Jak wspaniały i piękny jest Boży świat!

Jak się zdaje, zapowiada to wiejską sielankę. Jednak już w drugiej zwrotce pojawiają się fabryki, które podmiot liryczny zostawił za sobą. W trzeciej liryczne „ja” deklaruje pogardę dla bogaczy i pragnienie braterskiej przyjaźni między ludźmi, ponieważ, jak czytamy w kolejnej zwrotce, smuci go, że w przemysłowym mieście ludzie stali się niewolnikami zysku. Całość wieńczą słowa odnoszące się już bezpośrednio do Łodzi - modlitwa o to, by miłość i prawda rozkwitały w niej jak flanela i szewiot:

\footnotetext{
5 Ten sam autor używa pseudonimów S. Zaks oraz Skaz (Закс С. - Сказ).
} 
Oryginat:

Я молю, чтоб там наш слух ласкали Не одни слова: кредит, учет, Чтоб любовь и правда процветали В Лодзи, - как... фланель и шевиот. (S. Zaks 1912)

\section{Tłumaczenie filologiczne:}

Modlę się, by nasz słuch pieściły Nie tylko słowa; kredyt, rozliczenie, Żeby miłość i prawda rozkwitały W Łodzi, - jak... flanela i szewiot.

Tę stylistyczną niespójność należało w tłumaczeniu zachować. Szczególnie zależało mi właśnie na ostatniej zwrotce. Tłumaczenie dosłowne nie było możliwe, choćby ze względu na brak rymu. Nie można też było zostawić w polskim tekście słowa „,rozliczenie”, dlatego pierwotnie zastąpiłam je „kwitem”, dzięki któremu można by utworzyć rym „kwit - tweed”. Jednak tweedu w Łodzi nigdy nie produkowano. Trzeba więc było znaleźć inny rodzaj materiału wełnianego, który wytwarzano w łódzkich fabrykach. Stał się nim ryps, produkowany w fabryce Juliusza Heinza. Teraz wypadało „porzucić” wszelkie kwity dłużne i utworzyć inny rym, skojarzony z rypsem. Poszukiwaną parą okazał się niedokładnie zrymowany z „rypsem” „zysk”:

Modlę się, by do uszu trafiały

Inne słowa niż kredyt i zysk;

Miłość, prawda - by nam rozkwitały

W Łodzi - tak jak... flanela i ryps.

Wypada odnotować, że taka stylistyczna rozbieżność znamionuje ironizujące teksty pojawiające się w łódzkiej rosyjskojęzycznej prasie. Mogą to być odwołania do romantycznej poetyki, jak również wspomniane wcześniej nawiązania do dzieł znanych twórców, jak w przypadku przytaczanego już zapożyczenia motta $\mathrm{z}$ wiersza Krasowa, czy też kojarzących się z Johannem Wolfgangiem Goethem słów: „Ты знаешь град...”. Incipitem „Ты знаешь град...” rozpoczynają się dwa wiersze opublikowane w łódzkiej prasie. $\mathrm{W}$ pierwszym $\mathrm{z}$ nich, podpisanym pseudonimem Skaz, pojawiają się one w pierwszym wersie (Skaz 1898), drugi - autorstwa Дяди Митяя, czyli Wujka Mitiaja - nie tylko rozpoczyna się cytowanymi słowami, ale nosi też taki tytuł (Dyadya Mityay 1905). W obu wypadkach łódzki Rosjanin z końca XIX i początku XX stulecia może kojarzyć owe słowa zarówno ze znaną pieśnią Mignon Kennst du das Land, wo die Zitronen blühn niemieckiego romantyka (Goethe, online), jak i z jej rosyjskim przekładem Fiodora Tiutczewa (Tyutchev 1851: 45) opublikowanym w 1851 roku, który rozpoczyna 
się mottem w języku niemieckim Kennst du das Land... oraz frazą „Ты знаешь край, где мирт и лавр растет..." (Czy znasz kraj, gdzie rosną mirta i laur...). Czytelnik rosyjski może również wiązać interesujące nas słowa z tekstem hrabiego Aleksieja Tołstoja, który w 1854 roku wykorzystał kompozycyjny schemat Goethowskiego wiersza (Tolstoy 1981: online) ${ }^{6}$, a w charakterze motta do swojego wiersza użył sformułowania: „Ты знаешь край, где все обильем дышит...” („Czy znasz kraj, gdzie wszystko dyszy obfitością...”). Jednak zarówno dziewiętnastowieczny, jak i współczesny Polak, w tym łodzianin, cytowaną frazę skojarzy raczej z pierwszym wersem Mickiewiczowskiego naśladowania Goethego: „Znasz li ten kraj, gdzie cytryna dojrzewa..." (Mickiewicz 1899: online).

Trzeba też dodać, że z tytułem i pierwszymi słowami wyraźnie kontrastuje tekst autorstwa Wujka Mitiaja, podejmujący m.in. problem częstych bankructw i ratowania się przed nimi pożarem, co polegało na podpaleniu swojego zrujnowanego interesu. Drugi z utworów, rozpoczynający się tymi samymi słowami, ukazuje fabryczną rzeczywistość, w której nawet „dziecię w kolebce” („малютка в колыбели”) zna się na tkactwie:

\section{Oryginał:}

Там знает уж малютка в колыбели, Как делают меланжи и фланели.

(Dyadya Mityay 1905)

\section{Tłumaczenie:}

Gdzie nawet dziecko, co ma lat niewiele, Potrafi wytkać melanż i flanelę.

\section{Tłumaczenie filologiczne:}

Tam nawet maleństwo w kołysce wie, Jak robi się melanże i flanele.

Dokonując wyboru między dwiema możliwościami przekładu słów „Ты знаешь град...”: Czy znasz gród... albo Znasz li gród..., w obu przypadkach zdecydowałam się pozostawić nawiązanie do Goethego. Pominęłam jednak znane polskiemu odbiorcy Mickiewiczowskie sformułowanie „Znasz li ten kraj..." na rzecz bardziej neutralnego (niekojarzonego z polskim poetą) „Czy znasz ten gród?”. Przy tym, w przeciwieństwie do współczesnego "miasta”, uwzględnienie archaizmu „gród” pozwoliło odtworzyć obecne w oryginale staro-cerkiewno-słowiańskie „град” i wprowadziło do wiersza element wysokiego stylu. Dzięki temu w tłumaczeniu udało się osiągnąć

6 Tołstoj opublikował swój tekst w 1854 r., dla potrzeb artykułu został on zaczerpnięty z późniejszego wydania. 
silniejsze akcentowanie niezgodności stylistycznej tytułu i incipitu oraz opisanej w wierszach rzeczywistości łódzkiej „ziemi obiecanej”, co wydaje się korzystne z punktu widzenia roli omawianych przekładów w dzisiejszej rzeczywistości, a przede wszystkim ich przeznaczenia jako ilustracji badań naukowych.

Kończąc już tę „gawędę”, chciałabym odnieść się do obecnych w rozpatrywanych tekstach wskazań na folklor rosyjski. Mam na myśli utwór zatytułowany w oryginale Подвиг дельного купиа (I.V. 1914), czyli „Wyсzyn (osiągnięcie, dokonanie) roztropnego (rozważnego, rzeczowego) kupca”. Ów wielki czyn sprowadza się do dokonania przez kupca-bankruta zakupów na kredyty, ofiarowane mu przez łódzkich fabrykantów sprzedających swój zalegający w magazynach towar, a następnie do niewykupienia owych długów i wyśmiania naiwności swoich ofiar. W tym przypadku postanowiłam wzmocnić zawartą w tytule ironię, wykorzystując skojarzenie z rosyjskimi opowieściami o czynach pochodzących z ludu bohaterów, takich choćby jak Подвиг купца Иголкина (Dokonanie kupca Igołkina) - historia dzielnego kupca z czasów Piotra I i wojny rosyjsko-szwedzkiej, ale również z popularną pieśnią do słów Iwana Nikitina: Ехал из ярмарки ухарь-купеи, (Jechał z jarmarku kupiec - zawiadiaka), której bohater uwodzi wiejską dziewczynę, płacąc jej srebrem. Stąd też polski ironicznie brzmiący tytuł nadany przeze mnie przekładowi Wielki wyczyn kupca-chwata.

Odnotuję też, że możliwe jest sięgnięcie przez autora tego wierszowanego felietonu, podpisanego inicjałami И.В. (I.W.), do prawdziwej historii kupca Siemiona Sawieljewicza Gołdobina z Carycyna, który w 1909 roku ogłosił bankructwo, zawiadamiając swoich wierzycieli, że nie ma środków finansowych pozwalających na spłatę zaciągniętych u nich długów. Z historii, która oparła się o sąd, Gołdobin wyszedł zwycięsko, większość wierzycieli nie otrzymała ani grosza, kupiec natomiast uzyskał kolejne kredyty i stał się bohaterem miejscowej legendy (Shkoda: online).

Tego typu historie, odnoszące się do miasta Łodzi i odznaczające się dużą dozą ironii, a jednocześnie będące satyrą na ówczesną łódzką rzeczywistość, opowiadano w prasie rosyjskojęzycznej dość często, zwykle we wspomnianych „rajosznych” felietonach, ale także w parodiach. Wyśmiewano w nich wielkie ambicje mieszkańców rozwijającego się, bogatego, przemysłowego miasta, przy jednoczesnej małomiasteczkowości i zaściankowości owego "grodu” i jego mieszkańców. Przykładem mogą być słowa cytowanego już felietonu Ужель мы не идем вперед? (Kuzmicz 1896), który wyśmiewał za- 
równo ogólnoludzkie, jak i wyraźnie łódzkie przywary, co zilustruję, przytaczając dwie zwrotki wiersza wraz z tłumaczeniem, do którego wprowadzono szereg elementów kompensujących powstałe w procesie translacji straty. $\mathrm{W}$ pierwszej $\mathrm{z}$ nich, $\mathrm{w}$ rosyjskim pierwowzorze, poza banalnym tematem historią związku małżeńskiego zawartego przez starego mężczyznę z młodą, piękną dziewczyną, zauważamy opozycje stylistyczne, takie jak zdrobniałe i potoczne, a nawet nieco lekceważące określenie „красоточка” („красотка” - ślicznotka) skojarzone ze staro-cerkiewno-słowiańską formą „младая” (neutralnie „молодая” - młoda), jak również ironicznie brzmiące połączenie określenia starego człowieka - „старик” oraz oficjalnego „всупить в брак” czy też wyrażenie o równie ironicznym wydźwięku „сыночка подарить” (podarować syneczka). Język polski nie operuje leksyką staro-cerkiewno-słowiańską, jednak przekład stara się kompensować rosyjskie stylistyczne opozycje dzięki połączeniu słownictwa oficjalnego: „piękna panna młoda” z potocznym:, starego poślubiła chłopa”, a także form przestarzałych: „przysięgę wypełniła” oraz kojarzonych z wypowiedziami charakterystycznymi dla tekstów religijnych: „synka staremu porodziła”, jak również ze słownictwem potocznym: „no i - szok”. Wszystko to łącznie pozwala kompensacyjnie odtworzyć charakter rosyjskiego pierwowzoru:

\section{Oryginal:}

$* * *$

Одна красоточка младая, Назад с 1/2 года лишь всего, Со стариком здесь в брак вступая, Клялась ему любить его. И клятву верно сохранила, Она ему верна, и вот, На днях сыночка подарила, Ужель мы не идем вперед? [...]

\section{Tłumaczenie:}

$* * *$

A pewna piękna panna młoda, $1 / 2$ roku temu było to,

Starego poślubiła chłopa, Przyrzekła wiernie kochać go. Swoją przysięgę wypełniła Była mu wierna, no i - szok, Synka staremu porodziła, Czyż nie jest to do przodu krok? [...]

Podobnie w zwrotce drugiej, gdzie należało uwzględnić łódzki kontekst opowiadania o kolei żelaznej. Tym razem ironia zawiera się w obrazie pociągu tak długiego, że sięga od Łodzi do Koluszek (rozciąga się więc na +/- $30 \mathrm{~km}$ ). Autor felietonu informuje swoich czytelników, że kolej łódzka jest tak szybka jak kula bądź orzeł, bo jeśli pasażer wsiądzie w Łodzi do ostatniego wagonu pociągu (w ogonie), to pierwszy wagon (łeb) w tej samej chwili pojawi się w Koluszkach. Dla zachowania wskazanych realiów należało pozostawić 
w tłumaczeniu Koluszki bądź wprowadzić do tekstu inne podłódzkie miasta, co jednak byłoby trudne, biorąc pod uwagę czasy, o których mowa. Ze względu na epokę zdecydowałam też o wprowadzeniu do tekstu docelowego rosyjskiej miary odległości - „wiorsta” i nieużywanego dzisiaj określenia „żelazna droga”. Uznałam również, że wypada odwzorować w polskiej wersji podobne jak w oryginale absurdalne zachwyty, które wzmocniłam nieco, dodając "grzmot” do świadczących o prędkości kolei porównań z „kulą” i „orłem”, co pozwoliło też uzyskać potrzebny rym: grzmot - lot:

\section{Oryginat:}

$* * *$

Вот наша, например, дорога

Ходила 20 верст лишь в час. Взгляните, братцы, слава Богу,

Как быстро бегает сейчас:

Вы в хвост лишь поезда взобраться

Успели в Лодзи здесь едва,

А уж в Колюшках показаться

Его успела голова.

Так может пуля только мчаться,

Или орел свершать полет,

Чего нам критики бояться -

Ужель мы не летим вперед?

\section{Tłumaczenie:}

$* * *$

A oto jest żelazna droga,

$\mathrm{W}$ godzinę wiorst 20 szła.

A teraz, patrzcie, chwała Bogu,

Galopem biegnie, $\mathrm{z}$ wiatrem gna:

I jeśli łapiąc kolej łódzką

W ogon pociągu ktoś by wsiadł,

W tej samej chwili przy Koluszkach

Głowa pociągu ujrzy świat.

Tak tylko kula lecieć może,

Orzeł tak prędki jest i grzmot.

Czemu krytyka bać się, Boże! -

Czyż nie jest to do przodu lot?

Ta ironia obecna jest $\mathrm{w}$ większości tłumaczonych przeze mnie utworów, nie tylko felietonów. Przykładem są liczne, przytaczane już parodystyczne teksty, choćby wiersz noszący w polskiej wersji tytuł Pieśn bałuciarza, którego fragment prezentuję poniżej:

\section{Oryginal:}

Собак ли я вижу бродячих, Луж ли вонючих, стоячих, Стою очарован картиной И нашей достойною гминой

Деревья ли козы ломают, Детей ли коровы бодают, Я мыслю: ну, что за картина! Ах, дельная, славная гмина! (Dyadya Mityay 1914)

\section{Tłumaczenie:}

Gdy psów ulicznych omijam stada, Kiedy kałuży smród mnie dopada, Widokiem jestem oczarowany, Czcigodną gminą, którą kochamy.

I kiedy kozy na drzewa skaczą, A krowy dzieci rogami znaczą, To myślę sobie, cóż za widoczek! Cudna jest gmina, po której kroczę! 


\section{Tłumaczenie filologiczne:}

Czy widzę włóczące się psy,

Czy kałuże smrodliwe, stojące,

Stoję zachwycony obrazkiem

I naszą czcigodną gminą

Czy kozy łamią drzewa,

Czy krowy bodą dzieci,

Myślę; no, cóż to za obrazek!

Ach, rozsądna (rzeczowa), cudna (świetna)

gmina!

Jak się zdaje, niezależnie od różnorodnych obserwowanych w polskiej wersji mikrotransformacji obrazu poetyckiego (rozszerzeń, redukcji i zmian) udało się w niej zachować charakter piosenki dziarskiego bałuciarza, jego fascynację swą „małą ojczyzną”, a jednocześnie wyraźną w oryginale prześmiewczą ironię.

Doskonale wyraża to także pochodzące $\mathrm{z}$ początku XX wieku motto niniejszego artykułu, prezentujące dwie zwrotki wiersza Juliana Tuwima Łódź (Tuwim: online).

Zmierzając do zakończenia prezentowanych przeze mnie rozważań, chciałabym wskazać na pewien kierunek badań, jakie moim zdaniem warto podjąć. Należałoby mianowicie zastanowić się nad problematyką tłumaczenia wierszy dokonywanego w konkretnym celu, jakim jest ukazanie ich na tle badania poświęconego określonej społeczności - w tym wypadku łódzkich Rosjan. Realizując taki cel, przekładowca staje się nie tyle tłumaczem poezji, ile cytatu poetyckiego, ponieważ przekładane przez niego teksty pełnią funkcję materiału ilustracyjnego. Wymusza to pewne decyzje translatorskie.

Wydaje się też, że taki kierunek badań jest jedną z możliwości zindywidualizowanego podejścia do translacji tekstów literatury pięknej, niezależnie od ich wartości artystycznej i od przyczynkowości takiego badania dzieła poetyckiego. Tłumacząc tego rodzaju teksty, w dodatku w wyraźnie określonym, a przy tym wcale nie artystycznym celu, trzeba pogodzić się ze specyfiką owego przekładu i nastawić się na realizację tego właśnie, wyznaczonego wcześniej celu praktycznego. Nie zwalnia to jednak tłumacza z koniecznej kreatywności i z poszukiwania twórczych rozwiązań, choć $\mathrm{w}$ ramach świadomie narzuconych samemu sobie ograniczeń. Innymi słowy, nawet 
niezbyt wysokich lotów tekst poetycki należy przełożyć tak, by nie ująć mu tej najmniejszej nawet dozy artyzmu, którą posiadał w oryginale. Jeśli nie jest to wyłącznie niosący informację dokument, zasługuje na dostosowanie do stanu pierwotnego artyzmu. Idzie tu o dostosowanie jego najistotniejszych $\mathrm{z}$ naszego punktu widzenia charakterystyk, a więc dominant translatorskich uwzględniających cel wyznaczony przez autorów opracowania. W naszym przypadku były to badania poświęcone dawnej Łodzi, w tym jej życiu literackiemu, a materiałem ilustracyjnym stała się przede wszystkim poezja „rajosznej”, przy tym odnoszącej się do konkretnej rzeczywistości włókienniczej Łodzi z czasów jej rozwoju przemysłowego, o satyrycznym charakterze. Zarówno charakterystyki formalne, jak i stylistyczne, ale również elementy dokumentujące epokę historyczną powinny więc były pozostać w wersji przekładowej.

Pozwolę sobie przypomnieć w tym miejscu słowa Jefima Etkinda o swobodzie tłumacza jako uświadamianej przez niego konieczności podporządkowania się prawom artystycznego świata oryginału (Etkind 1975: 45) oraz Jeana-René Ladmirala, który twierdził, że skazany na wolność tłumacz musi podejmować decyzje (Ladmiral 1986: 35). Oba te twierdzenia doskonale wpisują się w koncepcję otwartej teorii przekładu skutecznego głoszonej swego czasu przez Zygmunta Grosbarta, koncepcję zezwalającą na swobodne czerpanie ze wszystkich teorii oraz na ich łączenie, o ile pozwoli to zrealizować cel, jakim jest dokonanie tłumaczenia (Grosbart 1998: 47-55).

Uważam, że niezależnie od rodzaju tekstu, jaki przekładamy, te trzy myśli należy traktować łącznie. Tłumacząc, musimy bowiem, jak pisał Grosbart, czerpać ze wszystkich możliwych teorii i źródeł praktycznych dla realizacji celu, jakim jest uzyskanie przekładu odtwarzającego dominujące charakterystyki tekstu. Myślę o tych jego charakterystykach, których zachowanie założyliśmy jako tłumacze. Chodzi tu z jednej strony o zachowanie charakterystyk wynikających z konieczności dostosowania się do tego, co zostało narzucone poza nami ( $w$ danym przypadku była to przede wszystkim funkcja pełniona przez wierszowane felietony w opracowaniu dotyczącym dawnej wielokulturowej Łodzi). Z drugiej strony - tych, które wynikały z celu, jaki postanowiliśmy osiągnąć, wprowadzając tekst do innej kultury. Swoboda twórcza tłumacza jest więc zgodnie z twierdzeniem Etkinda ograniczona koniecznością, ale decyzje o stopniu tego ograniczenia i o pewnej rozmytości brzegów wyznaczonych przez nią granic podejmuje, zgodnie ze stwierdzeniem Ladmirala, sam tłumacz, ponieważ tylko on może 
podejmować twórcze decyzje, które pozwalają mu kreować tekst i osiągać określone cele.

Wydaje się też, że w kontekście rozmytych brzegów linii granicznej między swobodą a koniecznością warto byłoby przyjrzeć się tej właśnie strefie, która dzięki rozmyciu powstaje między dwiema nieostrymi liniami brzegowymi - rozmycie daje nam bowiem pewną przestrzeń. To w jej zakresie znajdują się potencjalne odpowiedniki wykorzystywane w procesie tłumaczenia. Zgodnie z teorią logiki rozmytej Lotfiego Askera Zadeha (Zadeh 1965: 339) są to wartości pośrednie, które leżą między fałszem, wyrażanym jako 0 , a prawdą, oznaczaną jako 1 . Taki obiekt matematyczny nazywany zbiorem rozmytym (ang. fuzzy set) można, jak się zdaje, wykorzystać także w badaniach przekładoznawczych, zarówno przy podejmowaniu decyzji translatorskich, jak i w krytyce tłumaczenia. Encyklopedia nauki (online) podaje jako przykład zbioru rozmytego określanie strefy między zimnem a gorącem, gdzie temperaturę oznaczoną pionową linią można uznać jednocześnie za stosunkowo zimną, ledwo ciepłą i niezbyt gorącą.

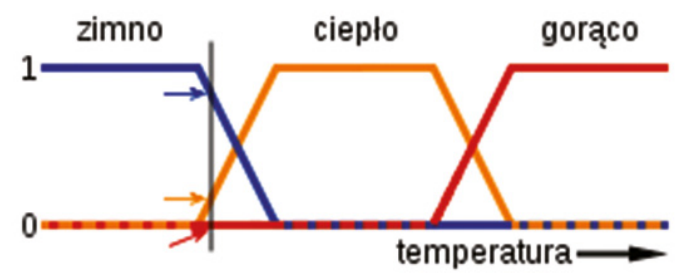

Rys. 2. Logika rozmyta, http://encyklopedia.naukowy. pl/Logika_rozmyta

Takich przykładów można podać więcej i wszystkie one opierają się na zmiennych lingwistycznych, a więc na wielkościach ocenianych dzięki wartościom lingwistycznym, będących słownymi ocenami owych wielkości. Przykładem może być przytoczone wyżej pojęcie temperatury i oceny jej zakresu, ale również stopień odpowiedniości danego transemu w konkretnej subiektywnie ocenianej sytuacji. Można więc wykorzystać teorię logiki rozmytej nie tylko przy lingwistycznych podsumowaniach relacyjnych baz danych, co w latach 70. proponował Zadeh (Zadeh 1975a: 199-249; 1975b: 310-357; 1975c: 43-80) i co kontynuowane jest przez współczesnych badaczy (zob. np. Kacprzyk, Yager 2001: 133-154; Niewiadomski 2006: 419-429), 
ale również do określania granic między fałszem a prawdą - adekwatnością i wiernością potencjalnych odpowiedników przekładowych, które sytuując się między swobodą a koniecznością, należą do pewnego zbioru rozmytego:

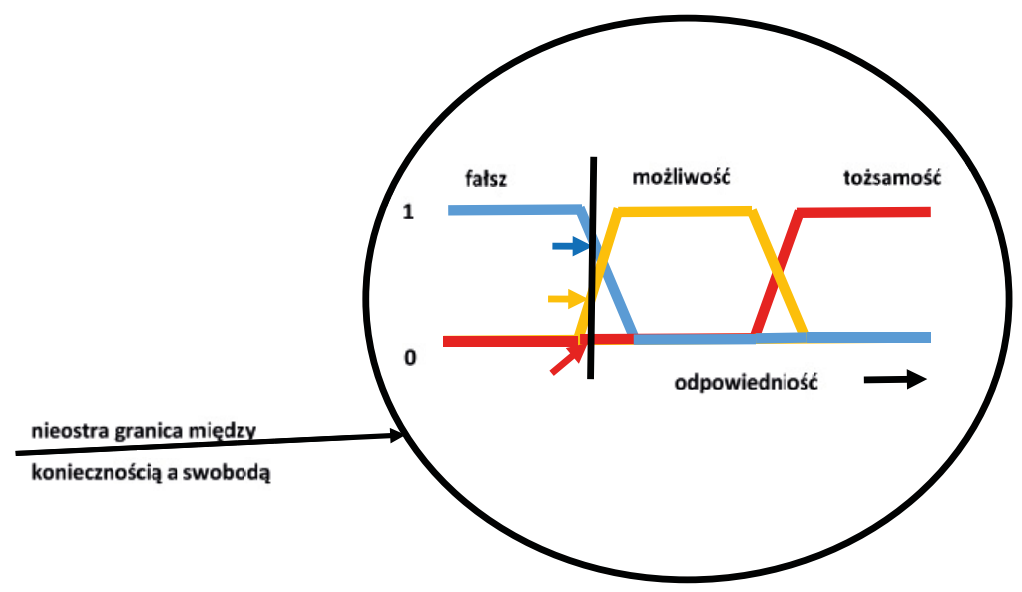

Mówiąc o potencjalnych odpowiednikach, nie myślę jednak o standardowych jednostkach przekładu na różnych poziomach języka, ale o wszelkiego rodzaju możliwościach, które tłumacz może wykorzystać, i zakładam sytuowanie się prawdopodobieństwa ich odpowiedniości między tym, co obiektywne - wynikające $\mathrm{z}$ konieczności, np. $\mathrm{z}$ dostosowywania się do nadrzędnego celu przekładu danego tekstu, i tym, co subiektywne - będące konsekwencją swobody twórczej i podejmowania decyzji najlepszych $\mathrm{z}$ naszego, indywidualnego punktu widzenia.

W wypadku rozpatrywanych przeze mnie utworów chodziło o takie ich przetransponowanie na inny grunt kulturowy, aby nie tyle się na nim przyjęly, ile były zrozumiałe, ilustrowały konkretne badania naukowe, a jednocześnie zachowały swój charakter wierszy rodem $z$ budy jarmarcznej ulokowanej pośród fabrycznych famuł, fabrykanckich pałaców, bałuckich bruków i zawsze blisko Piotrkowskiej, wierszy, w których miłość do miasta łączyła się z ironią zrodzoną z dostrzegania wszelkich jego braków. Ramy te można uznać za granice makrotekstu, którego zachowaniu służyły także przekształcenia na poziomie mikro, a więc modyfikacje translatorskie wykorzystujące rozmyte granice między zerowym odpowiednikiem a jego słownikową jednoznacznością, gdzie lokują się możliwości przekładu i twórcze wybory tłumacza. 


\section{Literatura}

Błok A.A., 1918, Dvenadcat [Блок А.А., 1918, Двенадцать], https://ilibrary.ru/ text/1232/p.1/index.html (dostęp: 2.05.2019).

Dyadya Mityay (L. Gr...van), 1904, Malen'kiy fel'yetonik, „Lodzinskij listok”, nr 97, 2 (14) grudnia [Дядя Митяй (Л. Гр...ван), 1904, Маленький фельетоник, „Лодзинский листок”, № 97, 2 (14) декабря].

Dyadya Mityay (L. Gr...van), 1905, Ty znayesh' grad?, „Lodzinskij listok”, nr 4, 6 (19) stycznia [Дядя Митяй (Л. Гр...ван), 1905, Ты знаешь град?, „Лодзинский листок”, № 4, 6 (19) января].

Dyadya Mityay (L. Gr...van), 1914, Pesnya balutskago obyvatelya, „Lodzinskij listok”, nr 131, 5 (18) lipca [Дядя Митяй (Л. Гр...ван), 1914, Песня балутскаго обывателя, „Лодзинский листок”, № 131, 5 (18) июля].

Etkind J., 1975, Swoboda tłumacza jako konieczność uświadomiona, tłum. E. Siemaszkiewicz, [w:] Przekład artystyczny. O sztuce tłumaczenia, ks. 2, S. Pollak (red.), Wrocław, s. 35-50.

Goethe von J.W., Kennst du das Land, wo die Zitronen blühn, https://kalliope.org/ da/text/goethe2001111901 (dostęp: 4.04.2019).

Grochowski P., 2010, Straszna zbrodnia rodzonej matki. Polskie pieśni nowiniarskie na przełomie XIX i XX w., Toruń.

Grosbart Z., 1998, Przesłanki opracowania „użytecznej” teorii przekładu, [w:] Przekład artystyczny a współczesne teorie translatologiczne, P. Fast (red.), Katowice, s. 47-55.

I.V. (pseud.), 1914, Zloby dnya, „Lodzinskij listok”, 5 (18) lipca [И.В., 1914, Злобы дня, „Лодзинский листок”, 5 (18) июля].

I.V. (pseud.), 1914, Podvig del'nogo kuptsa, „Lodzinskij listok”, 5 (18) lipca [И.В., 1914, Подвиге дельного купца, „Лодзинский листок”, 5 (18) июля].

Kacprzyk J., Yager R.R., 2001, Linguistic Summaries of Data Using Fuzzy Logic, „International Journal of General Systems”, nr 30, s. 133-154.

Krasov V.I., nie później niż 1841, Stansy [Красов В.И., не позднее 1841, Стансы], https://ru.wikisource.org/wiki/Я_вновь_пред_тобою_стою_очарован (dostęp: 2.05.2019).

Kuzmicz (pseud.), 1895, Ya vnov' pred toboyu stoyu ocharovan..., „Lodzinskij listok”, nr 102, 25 grudnia (6 stycznia) [Кузьмич, 1895, Я вновь пред тобою стою очарован..., „Лодзинский листок”, № 102, 25 декабря (6 нваря)].

Kuzmicz (pseud.), 1896, Uzhel' my ne idem vpered, „Lodzinskij listok”, nr 232, 27 października (8 listopada) [Кузьмич, 1896, Ужель мы не идем вперед, „Лодзинский листок”, № 232, 27 октября (8 ноября)]. 
Kviatkovskii A.P., 1966, Poeticheskiy slovar', Moskva [Квятковский А. П., 1966, Поэтический словарь, Москва], http://bukvitsa.com/20073/ bs_120333500_03_kvyatkovskiy_raek.html (dostęp: 4.04.2019).

Ladmiral J.-R., 1986, Sourciers et cibilistes, „La traduction. Revue d-esthetique nouvelle série", $\mathrm{nr} 12$, s. 33-42.

Mickiewicz A., 1899, Do $H^{* * *}$. Wezwanie do Neapolu, [w:] A. Mickiewicz, Poezye Adama Mickiewicza, t. 1: Poezye miłosne i elegie, https://pl.wikisource.org/wiki/ Do_H(enryki_Ankwicz\%C3\%B3wny)._\%E2\%80\%94_Wezwanie_do_Neapolu (dostęp: 4.04.2019).

Niewiadomski A., 2006, News Generating via Fuzzy Summarization of Databases, „Lecture Notes in Computer Science” 3831, s. 419-429.

Pushkin A.S., 1959-1962, Skazka o pope i o rabotnike yego Balde, [w:] A.S. Pushkin, Sobraniye sochineniy v 10 tomakh, t. 3: Poemy, Skazki, Moskva, s. 303-308 [Пушкин А.С., Сказка о попе и о работнике его Балде, [w:] А.С. Пушкин, Собрание сочинений в 10 томах, т. 3: Поэмы, Сказки, Москва, с. 303-308]. Shkoda R.V., Delo kuptsa Goldobina [Шкода P.В., Дело купца Голдобина], http:// xn--80aqpk2ad9a.xn--plai/article/articlestsaritsyn/263-goldobin.html (dostęp: 4.04.2019).

Skaz (pseud.), 1905, Lodz' Parodiya, „Lodzinskij listok”, nr 21, 2 (15) lutego [Сказ (pseud.), 1905, Лодзь (Пародия), „Лодзинский листок”, № 21, 2 (15) февраля]. Skaz (pseud.), 1898, Ty znayesh' grad..., „Lodzinskij listok”, nr 223, 21 października (2 listopada) [Сказ, 1898, Ты знаешь град..., „Лодзинский листок”, № 223, 21 октября (2 ноября)].

S. Zaks (pseud.), 1912, Vykhozhu ya na prostor zeleny, „Golos Lodzi”, nr 2, 9 (22) grudnia [С. Закс, 1912, Выхожу я на простор зеленый, „Голос лодзи”, № 2, 9 (22) декабря].

Tolstoy A.K., 1854, Ty znayesh' kray, gde vse obil'yem dyshit, [w:] A.K. Tolstoy, 1981, Sochineniya v 2-kh t., t. 1: Stikhotvoreniya 1840-kh., Moskva [А.К. Толстой, 1854, Ты знаешь край, где все обильем дышит?, [w:] А.К. Толстой, 1981, Сочинения в 2-х т., т. 1: Стихотворения 1840-х., Москва: Художественная литература], https://ru.wikisource.org/wiki/Ты_знаешь_край,_где_всё_ обильем_дышит_(А._К._Толстой) (dostęp: 4.04.2019).

Tuwim J., Łódź, https://literatura.wywrota.pl/wiersz-klasyka/38257-julian-tuwim-lodz.html (dostęp: 2.05.2019).

Tyutchev F.I., 1851, Ty znayesh' kray, gde mirt i lavr rastet (iz Gete), [w:] F.I. Tyutchev, 2003, Polnoye sobraniye sochineniy i pisem v shesti tomakh, t. 2: Stikhotvoreniya, 1850-1873, Moskva, s. 45 [Тютчев Ф.И., 1851, Ты знаешь край, где мирт и лавр растет (из Гете), [w:] Ф.И. Тютчев, 2003, Полное собрание сочинений и писем в шести томах, т. 2: Стихотворения 1850-1873, Москва, с. 45].

Zadeh L.A., 1965, Fuzzy sets, „Information and Control”, t. 8, s. 338-353. 
Zadeh L.A., 1975a, The concept of linguistic variable and its application to approximate reasoning - I, „Information Sciences”, t. 8, nr 3, s. 199-249.

Zadeh L.A., 1975b, The concept of linguistic variable and its application to approximate reasoning - II, „Information Sciences”, t. 8, nr 4, s. 310-357.

Zadeh L.A., 1975c, The concept of linguistic variable and its application to approximate reasoning - III, „Information Sciences”, t. 9, nr 1, s. 43-80.

\section{The tale about a rayok with factories in the background}

\section{Summary}

The article addresses the issue of the translation of a poetic feuilleton, which provides illustrative material for other academic research. The achievement of this purpose imposes certain choices on the translator, just as the temporal distance between the creation of the original and the translation does. Therefore, besides presenting practical translation solutions, the article refers to the concept of selecting equivalents from potential choices and proposes using the theory of fuzzy logic, owing to which it is possible to blur the boundaries between the creative freedom of the translator and the necessity of its limitation.

Fragments of the poetic feuilleton come from the poems published in Russian press in Łódź at the end of the $19^{\text {th }}$ and the beginning of the $20^{\text {th }}$ centuries. Their translations were used in a research project devoted to the multicultural literature of Łódź and its presence in the local foreign-language press published in the city at the time.

As the translated texts concern the reality of Łódź and the problems of its residents, the translation must take into account the realities typical of the city. Consequently, the translator's decisions were not focused solely on preserving the form and the lexical-semantic plane of the poem. They had to consider the cultural characteristics related to historical distance on the one hand and regional specificity on the other. Moreover, in some cases it was necessary to take into account references to Russian culture (primarily literature) and to decide whether they should be recreated in translation.

Keywords: rayok, reality, irony, potential possibilities, fuzzy set, translation

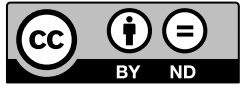

